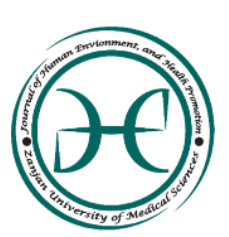

Journal of Human, Environment and Health Promotion

Journal homepage: www.zums.ac.ir/jhehp

\title{
Fluoride levels in Soil and Crops of Tomato and Onion Farms of Zanjan
}

\section{Khalilollah Moeinian a , Mohammad Reza Mehrasbi ${ }^{\text {b }}$, Hassan Hassanzadazar ${ }^{c}$, Koorosh Kamali ${ }^{\mathrm{d}}$, Elaheh Rabiei e,*}

${ }^{a}$ Department of Environmental Health Environmental Health Engineering, School of Public Health, Semnan University of Medical Sciences, Semnan, Iran.

${ }^{b}$ Department of Environmental Health Engineering, School of Public Health, Zanjan University of Medical Sciences, Zanjan ,Iran.

${ }^{c}$ Department of Food Safety and Hygiene, School of Public Health, Zanjan University of Medical Sciences, Zanjan, Iran.

${ }^{d}$ Department of Public Health, School of Public Health, Zanjan University of Medical Sciences, Zanjan, Iran.

${ }^{e}$ Department of Public Health Food Safety Health, Zanjan University of Medical Sciences, Iran.

*Corresponding author. E-mail address: elahe.rabeiee@yahoo.com

\section{A R T I C L E I N F O}

Article history:

Received October 13, 2016

Accepted December 1, 2016

Article Type:

Original Article

\begin{abstract}
A B S T R A C T
Background: Fluoride is an essential nutrient for the human body. The major routes of fluoride intake include food and drinking water, though the absorption of fluoride from food is much easier. The aim of this study was to evaluate the amount of fluoride in the soil and tomato and onion crops on farms of Zanjan.

Methods: Three farms of each crop (tomato and onion) were selected randomly. Each farm was divided into 10 sections, and one sample of soil and crop of each section was taken which means 120 samples in total. Fluoride concentrations in the soil and crops were measured using the Ion Selective Electrode (ISE) and repeated 3 times.

Results: The mean concentration of fluoride in soil samples from studied farms in Zanjan was $0.83 \pm 0.17 \mathrm{mg} / \mathrm{kg}$. The mean concentrations of fluoride in tomatoes and onions of Zanjan were observed $2.10 \pm 0.80$ and $2.23 \pm 0.64 \mathrm{mg} / \mathrm{kg}$, respectively.

Conclusion: There was no significant difference between fluoride concentration in tomatoes and onions, although there was a significant difference between the amount of fluoride in the soils of studied farms $(\mathrm{Pv}<0.024)$. No significant correlation was observed between the fluoride levels of soils and the fluoride levels of tomatoes $\left(R^{2}=0.126\right)$ and onions $\left(\mathrm{R}^{2}=0.008\right)$.
\end{abstract}

\section{Introduction}

Fluoride is one of the most beneficial micronutrients for the human body. Much of fluoride in the body is stored in skeletal tissue.

Although its role in tooth and bone health has been proven $[1,2]$, in excess, it can harm the body in many ways [3].

Based on the amount and the duration of exposure to fluoride, its complications can vary from mild dental fluorosis to crippling skeletal fluorosis [1]. 
In a cohort study conducted in China between 1998and 2008, a steady and strong relationship between high doses of fluoride and reduced IQ was observed [3]. Also, an epidemiological study in the United States showed that an increase in the amount of fluoride in drinking water causes changes in both male and female sex hormone levels and thus reduces fertility [4]. Fluoride ion prevents glycolysis by inhibiting some enzymes causing an increase in blood sugar levels. Also, since diabetic patients consume more water than healthy people, fluoride accumulation and excretion through the kidneys leads to renal dysfunction [5-7]. Absorption of 1-3 mg fluoride per day helps to prevent tooth decay [8]. Fluoride intake in children was $0.05 \mathrm{mg} / \mathrm{kg}$ in areas with 1 ppm fluoride concentration in drinking water.

Whereas in general, the optimal fluoride intake in adults is $0.07 \mathrm{mg}$ per $\mathrm{kg}$ of body weight per day $[9,10]$. Normally, adequate daily intake of fluoride for Infants up to 6 months; children aged 6 months to 2 years old; 8 years old; and adult male and female $0.01 \mathrm{mg} / \mathrm{kg}$ body weight, $0.05-0.1,3$ and 4 $\mathrm{mg} / \mathrm{kg} /$ day, respectively.

The United States Department of Agriculture (USDA) reported that about $75 \%$ of fluoride intake to body was through diet, water, and juices [11].

Cengeloglu et al., stated that fluoride pollution of the earth is created in two ways: natural and anthropogenic [12]. As WHO reports, minerals and large discharges into subsoil water sources of fluorine contained in rocks are natural sources of fluoride pollution [8]. Anthropogenic fluoride contamination is created by human activities like motorization, fluoridation of drinking water supplies (Low and Bloom), industrialization and utilization of fluoride- containing fertilizers and pesticides [13].

According to $\mathrm{WHO}$, recommended amount of fluoride in drinking water is 1-1.5 mg [1].

Averagely, most foods have 0.2-0.3 ppm of fluoride, except tea that has 10-75 ppm and seafood that have about 5-15 ppm of fluoride [14].
In most regions of Iran, the amount of fluoride in drinking water is below standard, level, the complications of the lack of fluoride is far more important than the complications of its excessiveness, and it is necessary to naturally compensate this lack of fluoride by ingestion of foods containing fluoride.

Food plays an important role in supplying the body's fluoride. Average consumptions of two commonly used crops, tomatoes and onions per capita in Iran were approximately $71.6 \mathrm{~kg}$ and 8$12 \mathrm{~kg}$ per year, respectively, especially in Zanjan province. Therefore, the aim of this study was to evaluate the fluoride content of tomatoes and onions and investigate the relationship between fluoride content of each crop with fluoride concentration in the soil of harvested farms in Zanjan city as the largest city of Zanjan province of Iran $[15,16]$.

\section{Materials and Methods}

This cross-sectional study was conducted on crops of 6 farms (3 Unigen tomato and 3 Yellow onion farms) that were selected randomly based on the location of the planting and harvesting of products in Zanjan city during the summer 2015 .

Each farm was divided into 10 sections and one sample of soil and crop was taken from each section which means 120 samples of soil, tomatoes and onions in total. All samples were dried under environmental conditions and then were ground and sieved. Fluoride concentrations in the soil and crop were measured using Fluoride Ion Selective Electrode (ISE) (PASCO scientific Model CI- 6728, USA).

At first, fluoride stock solution was prepared using sodium fluoride (NaF) (Merck, Darmstadt, Germany) with a concentration of $22.1 \mathrm{mg}$ per liter, then a standard curve was provided using 0 , $0.01,0.05,0.1,0.2,0.3,0.4,0.5 \mathrm{mg}$ per liter concentrations of standard solutions.

Sample preparation of the crops was conducted by grinding two grams of tomato and onion samples and boiling with $20 \mathrm{cc}$ distilled water. 
Samples were covered with aluminum foil and maintained at room temperature for 2 hours.

Then, brewed samples were transferred to test tubes and centrifuged for 30 minutes at 3,000 rpm.

$5 \mathrm{cc}$ of sample extracts was mixed with $5 \mathrm{cc}$ of total ionic strength adjustment buffer (TISAB) to maintain the ionic strength of the solution and eliminate the influence of interfering ions. In the end, fluoride content was read using ion selective electrodes (PASCO scientific Model CI-6728, USA).

For soil samples preparation, at first all soil samples were transferred to the laboratory, dried, crushed and passed through two-millimeter sieve.

Then 16 grams of soil sample was mixed with $50 \mathrm{ml}$ of calcium chloride $0.01 \mathrm{~mol} / \mathrm{l}$ and was placed in a shaking incubator for 16 hours at $25^{\circ}$ C. Samples were filtered and mixed with an equal amount of the TISAB solution. In the end, fluoride content was read using ion selective electrodes (PASCO scientific Model CI-6728, USA) [17].

Fluoride concentration of the samples was determined using the read values with a drawn calibration line.

Statistical analysis of the results was performed using SPSS ver. 22 software and Mann-Whitney and Kruskal-Wallis tests with a $95 \%$ confidence interval.

Statistical analysis of results was performed using SPSS ver. 22 software and Mann-Whitney and Kruskal-Wallis tests with a $95 \%$ confidence interval.

\section{Results and Discussion}

According to table 1, the average amounts of fluoride are $0.83 \pm 0.17 \mathrm{ppm}$ in the soil, $2.10 \pm$ $0.80 \mathrm{ppm}$ in the Unigen tomatoes and $2.23 \pm 0.64$ ppm in yellow onions.

The average and maximum concentrations of fluoride in the soil of northwestern region of Zanjan were $0.83 \pm 0.17 \mathrm{mg} / \mathrm{kg}$ and $1.23 \mathrm{mg} / \mathrm{kg}$, respectively.
Mirghaffari and Shariatmadari evaluated the mean concentration of soluble fluoride in the soil samples around major industrial centers in Isfahan using ISE method which was $1.0 \mathrm{mg} / \mathrm{kg}$. Maximum reported amount was $3.2 \mathrm{mg} / \mathrm{kg}$ that showed higher levels of fluoride compared to our study findings [17].

Istvan Pais and Benton Jones (1997) in their book have reported the fluoride concentrations in soil between 10 to $20 \mathrm{mg} / \mathrm{kg}$ [18]. Arnesen and coworkers have reported the concentration of fluoride in soil extracts taken from different depths and distances around aluminum plants in Norway between 5 - $35 \mathrm{mg} / \mathrm{kg}$ [19].

Utilization of Phosphate fertilizers is one of the main causes of fluoride contamination of soil since they contain under 1 to over $1.5 \%$ Fluorine. Phosphate fertilizers play an essential role in maintaining farm productivity. However, as they are made from phosphate rocks that formed millions of years ago, they contain a range of minerals other than phosphorus one of which minerals is fluoride [20].

The difference in fluoride concentration in farm soils in Zanjan ( $\mathrm{Pv}<0.024)$ was significant, which probably could be related to soil characteristics such as $\mathrm{pH}$, mineral composition and utilization range of phosphate fertilizers by farmers $[16,17$, 18]. Moreover, the mean concentrations of soluble fluoride in Unigen tomato and yellow onion samples in Zanjan were $2.10 \pm 0.80 \mathrm{mg} / \mathrm{kg}$ and $2.23 \pm 0.64 \mathrm{mg} / \mathrm{kg}$, respectively .

In Mirghaffari and Shariatmadari's study, the usual amount of fluoride in plants has been reported to be 0.2 - $20 \mathrm{mg} / \mathrm{kg}$ [17].

The United States Department of Agriculture (USDA) has reported the mean fluoride content of most foods including fresh raw tomato and onion $0.02 \mathrm{ppm}$ and $0.01 \mathrm{ppm}$, respectively [11].

McClurre has reported the average fluoride concentrations of $0.24 \mathrm{mg} / \mathrm{kg}$ in dry tomatoes and $2.4 \mathrm{mg} / \mathrm{kg}$ in dry onions that show proximity to obtained results [14]. 
In a study conducted in villages of India, on measurement of fluoride in some crops using ion selective electrodes, mean concentrations of fluoride in onions in two villages were $5.67 \pm 0.10$ $\mathrm{mg} / \mathrm{kg}$ and $10.50 \pm 0.09 \mathrm{mg} / \mathrm{kg}$ respectively. Also, the mean fluoride concentration in tomatoes was reported $13.48 \pm 0.08$ micrometers [21] indicating the results that are much higher than our present study results.

Table 1: Average Fluoride contents in the soil, Unigen tomatoes and Yellow Onions of Zanjan city.

\begin{tabular}{cccccc}
\hline Sample & Numbers & Mean $(\mathbf{p p m})$ & $\begin{array}{c}\text { Standard } \\
\text { Deviaton }(\mathbf{p p m})\end{array}$ & Maximum (ppm) & Minimum (ppm) \\
\hline Soil & 60 & 0.83 & 0.17 & 1.23 & 0.42 \\
$\begin{array}{c}\text { Unigen } \\
\text { Tomatoes }\end{array}$ & 30 & 2.10 & 0.80 & 4.88 & 1.17 \\
Yellow onion & 30 & 2.23 & 0.64 & 3.74 & 1.08 \\
\hline
\end{tabular}

Statistical analysis showed a significant difference between fluoride concentration in the tomato samples of three farms $\left(\mathrm{P}_{\mathrm{V}}<0.001\right)$, while there was not statistically significant difference in onions of different farms $\left(\mathrm{P}_{\mathrm{V}}<0.01\right)$; thus it seems that the type of product can have an impact on fluoride uptake from the soil.

Despite significant differences between the soil fluoride of studied farms $\left(\mathrm{P}_{\mathrm{V}}<0.024\right)$, a strong correlation was not observed between the concentration of fluoride of soils on farms and the fluoride of tomatoes $\left(R^{2}=0.126\right)$ and onions $\left(R^{2}=\right.$ 0.008). Overall, the evidence suggests that the fluoride of soil has a slight (if any) impact on the fluoride content of crops [14].

There were some limitations on this study design including the bias that may have occurred in collection of soil sample regarding the depth and size of samples collected, thus based on preliminary findings of this study, to assess more accurately, sampling must be done at different distances and in greater numbers. Since numerous studies suggest that fluoride uptake by leafy vegetables is naturally higher than non-leafy ones, the crop selection as samples may result in selection bias. In the present study we investigated fluoride content of irrigation water that can cause the bias of finding the probable cause of fluoride content increase.

\section{Conclusion}

Regarding the above mentioned limitations, it could be concluded that most of the investigated soil and samples have fluoride levels under critical limits. However, continuous monitoring of fluoride should be taken into consideration in other agricultural crops particularly leafy vegetables.

Precautions must be taken in the utilization of the crops as continuous ingestion may result in considerable increase in the daily dietary intake leading to deleterious bioaccumulation in the human body. Finally it is recommended that farmers be educated to use agricultural fertilizers properly, especially phosphate fertilizers.

\section{Acknowledgement}

We would like to express our gratitude to ViceChancellery of Research and Technology of Zanjan University of Medical Sciences for their financial support.

\section{References}

1. Dey S, Giri B. Fluoride Fact on Human Health and Health Problems: A Review. Med Clin Rev. 2016.

2. Battaleb-Looie S, Moore F, Malde M, Jacks G. Fluoride in Groundwater, Dates and Wheat: Estimated Exposure Dose in the Population of 
Bushehr, Iran. J Food Compost Anal. 2013; 29(2): 94-9.

3. Choi AL, Sun G, Zhang Y, Grandjean P. Developmental Fluoride Neurotoxicity: A Systematic Review and Meta-Analysis. Ehp. 2012; 120(10): 1362-1368.

4. Freni SC. Exposure to High Fluoride Concentrations in Drinking Water is Associated with Decreased Birth Rates. J Toxicol Environ Health A. 1994; 42(1): 109-21.

5. Qin J, Chai G, Brewer JM, Lovelace LL, Lebioda L. Fluoride Inhibition of Enolase: Crystal Structure and Thermodynamics. Biochem. 2006; 45(3): 793-800.

6. Prystupa J. Fluorinea Current Literature Review. An NRC and ATSDR Based Review of Safety Standards for Exposure to Fluorine and Fluorides. Toxicol Mech Methods. 2011; 21(2): 103-70.

7. Priya B, Anitha K, Mohan EM, Pillai K, Murthy P, Nadu T. Toxicity of Fluoride to Diabetic Rats. Fluoride. 1997; 30(1): 51-8.

8. World Health Organization (WHO). Chapter 6.5: Fluorides. Air Quality Guidelines, 2nd edn, WHO Regional Office for Europe, Copenhagen. 2000; 9.

9. Corea G, Fattorusso E, Lanzotti V, Capasso R, Izzo AA. Antispasmodic Saponins from Bulbs of Red Onion, Allium Cepa L. var. Tropea. J Agric Food Chem. 2005; 53(4): 935-40.

10. Yuwono M. Determination of Fluoride in Black, Green and Herbal Teas by Ionselective Electrode Using a Standard-Addition Method. Dent J (Majalah Kedokteran Gigi). 2005; 38(2): 91-5.

11. Cutrufelli R, Pehrsson P, Haytowitz D, Patterson K, Holden J. USDA National Fluoride Database of Selected Beverages and Foods.

USDA. 2005.
12. Cengeloglu Y, Esengul K, Ersoz M. Removal of Fluoride from Aqueous Solution by Using Bauxite Wastes. Sep Purif Technol. 2002; 28: 816.

13. Paul ED, Gimba CE, Kagbu JA, Ndukwe GI, Okibe FG. Spectrometric Determination of Fluoride in Water, Soil and Vegetables from the Precinct of River Basawa, Zaria, Nigeria. J Basic Appl Chem. 2011; 1(6): 33-8.

14. McClure F. Fluorine in Foods. Public Health Rep. 1949; 64: 1061-74.

15. Bergougnoux V. The History of Tomato: from Domestication to Biopharming. Biotechnol Adv. 2014; 32(1): 170-89.

16. Ghaffari H, Sheikhdarabadi MS, Marghoub N, Hakimi A, Ghermezgoli KM. The Effect of Size, Compression Speed and Axes on Mechanical Properties of Three Iranian onion Varieties. Int J Agric Crop Sci. 2013; 6(19): 1359.

17. Mirghaffari N, Shariatmadari H. Distribution of Fluoride in Groundwater, Soil and some Crops in Isfahan Region. JWSS. 2007; 11 (41): 43-51.

18. Istvan Pais J, Benton Jones JR. The Handbook of Trace Elements. Fluoride: CRC Press; 1997.

19. Arnesen A, Abrahamsen G, Sandvik G, Krogstad T. Aluminium-Smelters and Fluoride Pollution of Soil and Soil Solution in Norway. Sci Total Environ. 1995; 163(1): 39-53.

20. Weinstein LH, Davison AW. Native Plant Species Suitable as Bioindicators and Biomonitors for Airborne Fluoride. Environ Pollut. 2003; 125(1): 3-11.

21. Bhargava D, Bhardwaj N. Study of Fluoride Contribution through Water and Food to Human Population in Fluorosis Endemic Villages of North-Eastern Rajasthan. Afr J Basic Appl Sci. 2009; 1(3-4): 55-8. 